\title{
4 \\ The Empowered Girl
}

Women and girls represent humankind's most valuable untapped natural resource.

BAN KI-MOON, UN SECRETARY GENERAL (2012) ${ }^{1}$

You arm a young woman with a decent education and you see her conquer the world.

MARYAM SHARIF, DAUGHTER OF THE PRIME MINISTER OF PAKISTAN, LEADING THE WHITE HOUSE'S LET GIRLS LEARN INITIATIVE IN PAKISTAN $(2015)^{2}$

Investing in girls and women is not only the right thing to do for them as individuals. It's also the smart thing to do for economies.

JIM YONG KIM, WORLD BANK PRESIDENT $(2016)^{3}$

On May 20, 2017, a member of the National Assembly of Pakistan, Musarrat Ahmad Zeb, claimed that the attacks on Malala Yousafzai were staged; she noted that, "I was approached for the same drama but refused as I was not interested in seeking asylum in another country.... My inner conscience has compelled me to spill the beans."4 She went on to name different girls from Pakistan, particularly those succeeding in formal schooling, calling them "not Malala." In other words, as the argument goes, there exist a number of girls in Pakistan who struggle to obtain an education but have not attained the same kind of attention that Malala has. That Malala is not unique, that she should not be seen as an exception. Such sentiments have widespread appeal in Pakistan. When Malala's autobiography was published, the chief of the All Pakistan Private Schools Federation, Kashif Mirza, noted that while the 152,00o private schools had supported her when she was shot, they had now decided to ban her book: she "was a role model for children, but this book has made her controversial... Through this book, she became a tool in the hands of the Western powers." 
What is it about Malala's articulation in Anglophone media cultures, and relatedly the kind of "educated girlhood" that she symbolizes and advocates for, that is so threatening? Why would some Pakistanis be against Malala but for the education of girls? What does this case reveal about the promises and anxieties attached to the figure of the educated girl in contemporary Pakistan? To explore these questions, I shift my focus back to the transnational discourse on girls' education that first drew my attention to this topic. I engage in a critical appraisal of the visions of ideal girlhood and the purpose of education posited in this discourse by situating it within the promarket, neoliberal turn that the development regime has taken during the past few decades. I then draw on my fieldwork in Pakistan to problematize the emancipatory reading of schooling by highlighting its affordances and limitations for girls from minority religious and low-income backgrounds.

\section{CONVERGING ON THE GIRL}

In the dominant discourse on girls' education, girls appear as ideal citizen-subjects who can contribute to their nations and families by taking personal responsibility for their welfare. This often means transforming themselves into workers, consumers, and entrepreneurs by acquiring an education. This promise of education is grounded in liberal humanist sensibilities that see schooling as one of the key practices that can equalize the playing field, give individuals the ability to enact freedom, increase their productivity, and enhance their competitiveness in the global market. In the context of the global South, where access to formal schooling, especially for girls, is limited in some areas, improving such access is posited as the solution to problems as wide-ranging as poverty, corruption, terrorism, and environmental degradation. Thus, a broad range of formal and informal actors and projects have emerged in recent decades that advocate for girls' education. It is this paradigm within which Malala, too, locates herself, as readers will recall from the first chapter. Furthermore, with the increasing strength of global norm-setting mechanisms ${ }^{6}$ - such as the UN declarations and goals (MGDs and SDGs) - as well as the proliferation of nonprofit, philanthropic, and corporate campaigns-such as Nike Foundation's Girl Effect or USAID's Let Girls Learn-ideas around girls' education have attained a commonsense status.

The notion that girls' education can solve a wide range of social problems has found resonance in Pakistan as well. For instance, in October 2015, the daughter of the then prime minister of Pakistan, Maryam Nawaz Sharif, paid a visit to the first lady of the United States, Michelle Obama, to express support for the Let Girls Learn initiative. During this meeting, Maryam Nawaz made the commitment that Pakistan will double its GDP spending on education (from 2 percent to 4 percent) and in return Michelle Obama announced a contribution of \$70 million toward Pakistani girls' education. ${ }^{7}$ This aid contribution was in addition to previous commitments. The promises to increase budget allocations to education, however, were 
not new; in 2008, the government of Pakistan had already committed to spending 4 percent of its GDP on education, a goal which it had been unable to meet. Similarly, a large number of corporate, philanthropic, nonprofit organizations, and foundations - both foreign and local-are now found in Pakistan that articulate some of the same systems of reasoning in relation to girls' education. This includes movements such as Girl Effect, Girl Rising, and the Malala Fund, transnational organizations such as Plan International, World Vision, and Pakistan Coalition for Education (whose partners include the Open Society Foundation and Oxfam), and celebrities such as Madonna. Madonna, for instance, sold a painting to establish girls' schools in Pakistan and Afghanistan, claiming: "I cannot accept a world where women or girls are wounded, shot or killed for either going to school or teaching in girls' schools. We don't have time to be complacent. ... I want to trade something valuable for something invaluable-Educating Girls!"'

Several scholars, however, have critiqued this "girling of development." While some interrogate the emancipatory promise of education that undergirds girls" education campaigns, ${ }^{9}$ others highlight the production of a homogenous girlsubject and female exceptionalism. ${ }^{10}$ Specifically, girls' education campaigns often posit girls in the global South as either heroines with extraordinary potential or as victims of poverty and patriarchal cultures to be freed by their counterparts in the global North. ${ }^{11}$ These binary subject positions reduce the complexities of the lives of girls and have often been used to legitimize western interventions. This "turn to the girl" in development can be situated within the wider valorization of postfeminist subjectivities in the context of neoliberalism, which prioritizes individual autonomy, choice, and agency, and places the burden of improving one's life on individuals themselves. Girls who abide by the neoliberal scripts of individualization, consumerism, and entrepreneurial identity are therefore marked as successful. ${ }^{12}$ However, both Anita Harris and Angela McRobbie direct attention to the racialized and classed character of this girlhood, noting that such life scripts are often available only to white, middle-class girls. They observe that in western contexts, girls who are unable to enact this vision of girlhood due to structural disadvantages - such as living in poverty or in neighborhoods rife with violence, crime, and drugs - are marked as "at-risk."13 They are folded into an intricate apparatus of surveillance, which includes school personnel, psychologists, and social workers. Girls in the global South, on the other hand, who, due to structural disadvantages, may be out of school, marry early, or engage in domestic/agricultural work to support their families become the specter of failed girlhood. They are variously marked as tribal, backward, or traditional. Often religion and culture are blamed for their wretched conditions, and their poor conditions are depoliticized and ahistoricized. These girls, however, are not written off. It is assumed that through proper education they too can be molded into "successful" girls. Hence, this new interest in girls' education and empowerment brings with it a significant regulatory aspect. More crucially, this discourse depoliticizes women's issues 
rather than calling on women to understand and resist the structures that create the conditions of their marginalization in the first place.

Joining this body of critique, in this and the following chapters I provide evidence from Pakistan that points to the ways in which social class, state practices, and norms of respectability and religious morality, mediate the lives of girls. In doing so, I also trace the contours of ideal/failed girlhoods in Pakistan today. These chapters aspire to go beyond the trend of painting neoliberalism as a bogeyman that magically infects everything, and instead show how it works-how transnational discourses are renegotiated in local contexts; how students, parents, and teachers are not necessarily passive pawns of neoliberal domination but strategically push back against elements of transnational discourses, and also at times mobilize neoliberal rationalities to their own advantage. ${ }^{14}$

I draw on focus-group conversations with girls, teachers, and parents in South Pakistan to provide a glimpse into the ways in which the promise of education unfolds in their lives. Their accounts complicate the neat and tidy narrative of education as empowerment. The case study shows that while schooling has provided some avenues for girls to participate in public life, concerns around respectability and marriageability, often articulated as lack of safe working conditions, mean that only low-income girls engage in waged work. Furthermore, since schools in Pakistan privilege the teaching of the dominant, Sunni, interpretation of Islam, my participants who belonged to a minority interpretation of Islam, expressed concerns around the erasure of their identity. The role of schools in producing ideal religious subjects, thus, continues to be as central as it was in the early days of Pakistan. Before delving into the case study, I situate the current turn to the girl within the broader dynamics in the field of international development.

\section{"PROMARKET DEVELOPMENT"}

Colonial relations of power based on territorial conquests have morphed into modes of human relationality that reproduce the colonial project's unequal distribution of epistemic, material, and aesthetic resources through renewed forms of division of labor, accumulation of capital, and imposition of racial and gender hierarchies. ${ }^{15}$ These renewed relations of domination advance the interests of global capital by transforming girls into cheap labor, consumers, and precarious entrepreneurs who willingly take on the burden of improving their own welfare without relying on the state. In other words, the construction of the ideal girl facilitates the withdrawal of the state via the empowerment of the individual. It hides the systemic practices that produce dispossession and displacement. It can, therefore, be read as a technique of neoliberal governmentality that puts the onus of solving social problems on the individual by acquiring appropriate knowledges and reshaping the self, rather than holding the state or global capital accountable. ${ }^{16}$ Schooling, in this context, often gets reduced to producing workers who can function in the neoliberal social order. 
The logics of transnational girls' education campaigns become meaningful against this convergence of the development regime with promarket practices.

Since World War II, institutions such as the World Bank and the International Monetary Fund (IMF), dominated by countries in the global North, in particular the United States, have played a critical role in framing and facilitating the economic development of newly independent nations in the global South. While having previously utilized Keynesian principles with its protectionist impulses, these institutions have shifted toward neoliberal logics since the 1970s. This shift, popularly known as the "Washington Consensus," proposes that privatization and deregulation of public assets and services is the best way to promote consumption, economic growth, and efficiency. It also advances understandings about human welfare and capacity in economic terms. The 1970 s debt crisis in third world economies created an opportunity for the IMF to transform these principles into practice through its Structural Adjustment Programmes (SAP). These programs often called for decreasing public expenditure on social services as a precondition for loans, thereby reducing the capabilities of the recipient states to provide welfare to their populations. Governments in the region eager for aid and loan monies readily implemented SAPs. It became clear over time that these policies, instead of helping the poor, deepened poverty and increased the vulnerability of the poor. Indeed, prior protectionist policies had sheltered not only the elites in these countries but also the working classes. A major contribution of neoliberal projects, then, has been the transfer of wealth from subordinate to dominant classes and from poor to rich countries, as well as large-scale displacement of the poor. ${ }^{17}$

This ascendency of economic measures to determine human well-being was criticized by proponents of the human capabilities approach. First introduced by Amartya Sen and extended further by Martha Nussbaum, the approach posits that economic measures such as GDP and GNP are not sufficient to determine human development. ${ }^{18}$ Instead, Sen noted that an individual's capability is determined by her ability to choose the particular functionings that she values. Enhancing an individual's agency and freedom, then, was critical for increasing her capability. Nussbaum extended Sen's theorizations by creating a list of ten "central human capabilities" that she deemed were necessary to pursue in order to achieve human development. ${ }^{19}$ The capabilities approach has been welcomed by some scholars who had long argued for international educational development agendas to move beyond issues of access to include a consideration of social justice. ${ }^{20}$ Other scholars, however, argue that this approach fails to account for the complex contexts of schooling. ${ }^{21}$ Postcolonial feminists, for instance, have criticized the capabilities paradigm for erasing the social stratifications that constitute women's lives, its impetus toward universalization, and its construction of culture and religion in monolithic and antagonistic terms. ${ }^{22}$ In my previous work, I too have attempted to expose the valorization of "choice" as the key element of the capabilities approach. ${ }^{23}$ Yet, the human capability approach remains one of the dominant paradigms in the 
field of development, one that sits alongside theories of human capital-at times in agreement, at other times in opposition.

More recently, in response to mounting critique of the Washington Consensus, a revised consensus, often called the "Washington Consensus Plus" or the "New Washington Consensus," has emerged. While aid and loans to developing countries continue to be tied to particular conditions around public expenditure, notions such as "good governance," "freedom," "empowerment," and "gender equality" are now used to legitimize these prescriptions. ${ }^{24}$ This new consensus is not a departure from market rationalities, but it is different in its ambition, as it endeavors to produce resilient market subjects for a globalized world and relies on micromarket transformations to compensate for macromarket failures. ${ }^{25}$ The "New Washington Consensus" has authorized an environment where for-profit corporations and philanthropic foundations can legitimately enter the field of development, take on the task of providing social services that were previously viewed as the responsibilities of the nation-state, and use market tools and mechanisms to deliver them. Significantly, for-profit corporations are viewed as capable advisors that can increase the efficiency of the development enterprise by infusing best practices. Katharyne Mitchell and Matthew Sparke describe this convergence of development and market agendas as "pro-market development." ${ }^{26}$ Girls have emerged as ideal sites for investment in order to achieve wide-ranging social and market goals. A brief example will clarify this convergence.

Consider the SPRING Initiative, a public-private partnership involving the USAID, the UK's Department for International Development, and the Nike Foundation that has been launched in Kenya, Rwanda, and Uganda, with plans for expansion to Pakistan. ${ }^{27}$ Part of USAID's broad range of interventions for "gender equality and women's empowerment," ${ }^{28}$ this initiative aims to support "businesses whose products and services could transform the lives of adolescent girls." A cursory review of the program's rationales illuminates the economic logics that inform it. The program seeks to "accelerate the economic empowerment of girls ... [and] will help businesses bring products to market which enable girls to learn, earn, invest and save." The initiative hopes to attract sponsors (established businesses from the West) who may be interested in mentoring entrepreneurs in the global South. It grounds its work in light of the fact that "right now, products and services are rarely designed for, marketed to, or distributed to the majority of the world's adolescent girls - they're a massively underserved market" (emphasis mine). Hence, to incite established businesses, SPRING provides opportunities for sponsors to "interact first-hand with SPRING enterprises, learn about new markets and opportunities for innovative practices, and directly engage employees and partners in our programme as mentors, coaches, and event speakers" (emphasis mine). Furthermore, to attract investors, it highlights "the rare opportunity to infuse capital into innovative, high-growth enterprises" and notes, "with your investment, 
SPRING businesses can embrace one of the greatest social opportunities of our time-adolescent girls-and deliver ROI while they're at it" (emphasis mine).

Clearly, the SPRING Initiative articulates girls in the global South as primarily an untapped market (of labor and customers) to be harnessed by local entrepreneurs and established, western sponsors/investors alike. Such projects imagine an economically savvy and financially self-disciplined subject, and unleash processes of subjectivation that can be read as part of the "triple movement" of the New Washington Consensus, which "shores up global market practices and rationalities through local social projects that at once acknowledge and cover for market failure while simultaneously cultivating new market subjects." ${ }^{29}$ Indeed, in the context of the 2008 financial crisis and the exhaustion of western markets, financial enterprises have had to aim elsewhere to remain profitable. The financial system has, thus, shifted to different "types of financial ecologies, those made up of less privileged individuals and households that are located more towards the margins of society." ${ }^{\circ}$ A move toward African and Asian markets, consumers, and labor through initiatives such as SPRING, then, could be read as a critical practice of transnational capital that facilitates the transformation of girls into economic actors and enrolls them in the (new) global economy, all the while benefiting large corporations.

Such promarket development projects advance a particular kind of rationality or valuation of human life and social projects. Here, all aspects of life are reduced to economic logics. The projects thus also produce governing logics around what it means to be modern, valuable, and empowered. Within this landscape, education continues to be a key site of investment as it straddles "both equity-and productivity_conceptualizations of development, while limiting commitment to stronger redistributive measures that might conflict with neo-classical economic theories." ${ }^{11}$ This is precisely what we observe in contemporary calls for girls' education, which highlight girls as potential sites of investment and link girls' education to economic growth. The World Bank's 2012 World Development Report, for instance, calls for investing in girls' education because it is "smart economics." In fact the World Bank, which initially did not have any mandates around education, is now ". . . the largest single international funder of education for development in low-income countries, and its technical and knowledge-based resources tower over those of other international institutions." ${ }^{2}$

Furthermore, promarket development approaches see women's empowerment as closely linked to women's access to education and the labor market. This logic presumes a direct correlation between women's economic independence and their quality of life as women. ${ }^{33}$ There is, then, extensive focus on attaining gender parity in the realm of education and employment. These ideas persist in spite of studies that show that education can be empowering as well as constraining. For example, even in countries where gender parity in education has been achieved, gender equality remains elusive. Consider Arlie Hochschild and Anne Machung's study 
in the context of the United States, which shows that middle- and upper-class women continue to remain responsible for household and care work even as they hold paid jobs in the formal sector. ${ }^{34}$ Likewise, professional women in India and Nepal end up taking additional responsibilities on the domestic front to exhibit their new educated selves. ${ }^{35}$ In Pakistan, Ayesha Khurshid's ethnographic study with female teachers shows that educated women not only have to excel in their new public roles but also their traditional roles as homemakers and childcare providers in order to prove that they deserve educational opportunities. ${ }^{36}$ Khurshid thus concludes that "this interplay between the traditional and new roles for educated women in the domestic sphere complicates the linear narrative of women's education that uses gender parity in public spheres as proxy for gender equality. Instead ... gender equality is a complex process shaped by structural inequalities and cultural norms that determine the meaning and purpose of education in a specific context." ${ }^{37}$

Likewise, Willy Oppenheim also contests the epistemological basis of the widely popular assertion that girls' education leads to reduction in fertility rates or reduces early marriage. He contends that such chains of reasoning are often premised on the idea that education increases women's autonomy in the household, an assertion that is debatable and difficult to prove. On the contrary, he points to other structural changes due to the provision of schooling that alter the calculus for educated as well as uneducated parents. So, changes in fertility rate may have less to do with women's empowerment and more with structural limitations/possibilities. ${ }^{38}$ In spite of this critique, gender parity approaches in girls' education remain dominant, and access to schooling persists as a paramount goal.

It is, therefore, not surprising that the government of Pakistan has also marked girls' access to schooling as a priority and sees girls through dominant framings of citizenship and future-labor. In fact, the very objective of education as outlined in the 2009 National Education Policy privileges the skills necessary for a neoliberal order and outlines the purpose of education as earning a living and preparing citizens:

The objective of education is the development of a self-reliant individual, capable of analytical and original thinking, a responsible member of his community and, in the present era, a global citizen. . . The other relevance of education is its ability to provide the graduates with an opportunity to earn a living. Education should be able to increase the earning potential of the individual who is literate; irrespective of the eventual vocation opted. ${ }^{39}$

The privatization of the education sector in Pakistan has not only introduced multiple new actors in the space, but has also facilitated the responsibilization of the citizen, ${ }^{40}$ as the onus of education is transferred from the state to parents and communities. In the 2009 National Education Policy, the government, in conjunction with celebrating "public-private partnerships," devolved the responsibility for 
education from the federal to the provincial level, thus taking a further step back in providing social services to its citizens.

While the state hopes to attend to girls' education and points to the Gender Parity Index (GPI) to show the disadvantage that girls and women face across the educational spectrum, ${ }^{41}$ its privileging of access and enrollment means that limited attention is paid to the quality of girls' education. Willy Oppenheim observes that the Pakistani policymakers' and researchers' focus on simply increasing girls' rates of enrollment and persistence in school distracts them from the fact that many of "Pakistan's educational gender gaps have shrunk dramatically over the past twenty years and thus risks missing the opportunity to explore the subtleties of this historic shift." 42 Likewise, we know very little about the ways in which ideas made common sense through the transnational discourse are taken up, modified, and resisted at the local level. Against this background, it is significant to explore girls' experiences of schooling in order to understand the opportunities as well precarities that schooling introduces in their lives. In other words, how is the empowerment and emancipation postulated by the transnational discourse on girls' education actually experienced by girls? Such an investigation also provides insights into emergent visions of girlhoods. With this objective, I conducted a qualitative study in Pakistan during 2015 with girls, parents, and teachers to examine their engagement with schooling. My hope was to explore how girls from minority religious and low-income backgrounds engaged with the enterprise of schooling.

\section{SCHOOLING GIRLS: A CASE STUDY}

I present key themes that emerged from twelve focus-group conversations with girls, parents, and teachers conducted in a small city in South Pakistan. In these conversations, I tried to understand the participants' experiences with formal schooling and the possibilities that schooling afforded them, as well as its limitations. I view this study as providing a peek into the complexities of schooling, particularly for those who are on the margins of society. First, I show that even as my participants-who were predominantly from lower-middle-class backgroundsunanimously agreed to partake in the enterprise of schooling, they recognized that its purpose varied for people from different social classes. While the majority of my participants saw schooling as a pathway to "office jobs," which was a code for work deemed respectable for middle-class women, they noted that girls from upper-class backgrounds consumed schooling primarily to secure good marriage prospects. Next, even as my participants engaged in schooling to access middleclass privileges, they realized that it might fail them because "office jobs," too, are classed and accessible only to those who have the requisite social capital. As a result, they critiqued the kind of education that was provided in schools which left them with limited options for respectable work. They called instead for more hunar-based training to secure an alternate, respectable life-script in the informal 
economy. Finally, since my participants belonged to a minority Muslim community, they saw official school knowledges - which inscribed the Sunni interpretation of Islam-as threatening their identity and desired greater attention to Shii religious education.

What we observe then are themes similar to those that appeared in chapters 2 and 3-the links across education, respectability, and social class, and anxieties around religious identity formation-but now in relation to different concerns. Schooling is articulated both as a social practice and as a commodity. It can signal social-class status through the kinds of opportunities that it can create-access to "safe" professions and better marriage proposals-and has the ability to reshape girls into subjects who can attract such possibilities. However, it can also be experienced in problematic ways, especially by those who are already situated on the margins of society due to their social class, gender, and/or religious interpretation. Together, these themes disrupt the flat, celebratory stance toward schooling posited by the development regime. They also provide insights into the making of girl-subjects in Pakistan.

\section{Focus-Group Site and Methods}

I collected data in a minority community of Shia Muslims in South Pakistan. I selected the community and city for several reasons. First, I grew up in this town and have worked with the same community-based organizations for the past decade. During this time, I have volunteered as a teacher and teacher educator, and have helped to raise funds for housing rehabilitation after floods and for scholarships for ultrapoor children. I have also conducted research in this community, which has been published. ${ }^{43}$ In other words, I bring to the study an intimate knowledge of the community, a commitment to enhancing its welfare, and an ethic of empathy. I recognize that my decade-long experience with this community influences my interpretation of the data. Second, this city was a good site for this study due to its location as a transition town between the rural areas of the province of Sindh and the nearby metropolitan city of Karachi. Often, people from the rural areas settle here first in the hopes of moving on to Karachi to find better work and/or educational opportunities. In recent years, the city has increasingly become a focus of investment from private corporations, having opened its first mall, Pizza Hut, and McDonald's. During the past decade, it has also seen the establishment of new curricular offerings-such as the British O- and A-levels system-previously only available in Karachi. While the community boasts some families who own land and may be constituted as elite or upper class, the majority reside in different multifamily complexes that can be mapped onto social class. The center, with high real estate prices, is occupied by the elite or upper middle class, and the periphery by middle-class and low-income families. The economic elite of the community as well as upper-middle-class families enroll their children in 
English-medium schools to pursue the British curriculum (much like elsewhere in Pakistan). Community members live in close proximity to each other and attend a local community center every evening. I visited the community center each evening, explained my project to prospective participants, and met with those who signed up the following day for interviews. I recruited participants through snowball sampling. After the interviews, participants would often ask their friends to participate as well. The local community-based organization, whose offices I used for conducting the interviews, also facilitated some introductions. Since I am also a member of this transnational Muslim community, it made recruitment much easier than it would have been for an outsider.

Overall, I conducted a total of twelve focus-group conversations-four of these were with teachers, three with parents, and five with female students between the ages of thirteen and twenty-one. Each focus group had a minimum of three and a maximum of five participants. Two parent groups, however, ended up having two members each because some parents did not arrive at their designated time and ended up joining another group (hence, one parent group had five instead of the assigned three participants). I used open-ended questions, including: What does education (ta'alim) mean to you? What is the purpose of education? Where does education take place? What limitations (if any) does formal schooling have? What changes would you want to see in your own schooling? During the focus groups with parents, the questions were reframed to be about their female children. Not all questions were asked in all focus group conversations. The themes that I discuss below emerge from the interview transcripts. I undertook thematic coding in order to highlight recurring themes and patterns in the participants' narratives. In addition, I commenced the process of analysis simultaneously with data collection. That is, after a few focus groups I evaluated the data for emergent findings and recurring themes, on the basis of which I modified the questions for subsequent groups in order to probe particular topics further. For instance, some of the female students emphasized how pressures of schooling were leading to a deprioritization of religious knowledges. To explore this theme further, I decided to add focus groups composed of teachers from the local Religious Education Center (REC). ${ }^{44}$ In these conversations I tried to explore teachers' own ideas about the need for religious education, the available spaces for such knowledges, and the difficulties their students were facing in accessing these knowledges. Thus, the exercise of data collection was a recursive process, which made the study a mobile, fluid project, amenable to taking new directions as and when needed.

The themes I present below are not representative of all Pakistani girls, parents, or teachers. Indeed, the minority religious positioning of my participants necessarily makes these themes specific. However, the interviews serve as clues toward broader problematics around gender and schooling, pointing to how social class 
mediates assumptions about ideal girlhood. These narratives also problematize the neoliberal celebration of individual autonomy, choice, and responsibility, which permeates current discourses on girls' education.

\section{NADIA: A SCHOOLED GIRL}

From a distance, Nadia (age seventeen) appears to be the ideal girl imagined by girls' education campaigns. She attends school regularly, obtains high grades, secured a scholarship from the U.S. Embassy to spend a year at an American high school, and has good facility with the English language. She is not interested in marriage right now, and wants to make money to secure material comforts for herself and her family. When asked to elaborate on her everyday routine, she explains that she attends school all day, followed by tutoring sessions and homework. She avoids social gatherings to ensure that she can get enough sleep. She willingly regulates her behavior, time, and social life in ways that produce the kind of ideal girlcitizen desired by the contemporary social and economic order. Nadia displays the "potential" of girls when they stay in school, and her subject position is desirable in terms of both social objectives and state planning.

A deeper conversation with Nadia, however, illuminates the range of social and economic precarities that schooling has introduced in her and her lowermiddle-class family's life. Nadia repeatedly referred to education as a "burden" (using the English word). She explained that education is not only a drain on her, as she has to struggle with academics at school and attend several tutoring sessions, but also for her family, as they have to sacrifice basic necessities to ensure that they have enough money to send her and her siblings to private schools. Given the low quality of education in public schools, any family that seeks to reap the promise of upward mobility via education must partake in expensive private schooling. Nadia's family has to deal with severe financial difficulties, including having to organize care for a disabled child, save for college expenses, and bear the high cost of schooling. She, then, argued that education was a burden for an entire range of actors who were involved in facilitating the process: "Whether we have food, housing, or other basic necessities does not matter. Due to education we have to kill our other basic necessities." Nadia's tone was angry and frustrated. Nadia found schooling to be all-consuming, leaving her with limited additional spaces to engender a sense of social belonging: "We are always either at school or at tuitions. I have lost my identity. I am only someone who went to [name of school] and did her O levels. That is the only way people know me. But education does not decide everything. Background and origins are important too but they are forgotten."

The terms "background" and "origins" in this context refer to a sense of local provincial and Shia identity. The majority of my participants were Sindhi and in the context of decades of suppression of their ethnic identity, they have developed 
a narrative that seeks to recenter this identity. This is further compounded by the fact that these participants are from a Shia minority community which fears that without the constant labor of sustaining its identity, they may be overwhelmed by the majority. In addition to a lack of belonging outside the identity of "student" and the labor of schooling, Nadia pointed out in a dejected tone, "learning has lost its own purpose ... I study for formality's sake, not for enjoyment or learning."

At the same time, Nadia observed that "education gives status", and that unless she attended an elite university she would not be able to obtain a good job or make a living. Nadia's equivalence of "status" with having a job and making a living signals that only when one has the latter can she be seen as a subject who has arrived, has made it, or is even an adult. This narrative points to the paradox, whereby in today's social order adult citizenship is no longer linked to age but to one's employment and dependency status. ${ }^{45}$ To become a fully participating adult citizen of society, Nadia has to become economically independent. However, longer periods of education and training, a precarious job market, and reduced state support translate into future uncertainties for individuals like Nadia, who are unable to achieve adulthood.

I open with Nadia's story because it signals the complicated ways in which schooling is consumed and experienced by girls from low-middle-income backgrounds in Pakistan today. It shows how social class, future job prospects, lack of quality public school education, and desire for religious belonging, intersect to inform schooling experiences.

\section{SCHOOLING AS PROPER CONSUMPTION}

The majority of my participants were from low-middle-income backgrounds. This often meant that their fathers were the primary breadwinners, their mothers were homemakers, and that they were enrolled in mid- to low-tuition private schools. With rising inflation and a stagnant job market, this gendered division of labor is becoming increasingly untenable for low-middle-income families. Hence, across the board my participants expressed the desire for education because they expected to enter the labor force. They often described schooling as a "pathway" (Erum, age fifteen) or "ladder" (Kiran, age thirteen) toward "success" (Naila, age sixteen), which entailed "having a good standard of living," "having a good job," or "making money" (Kiran, Erum, Naila, respectively). There was consensus among these participants that in order to progress in life one had to follow a particular life-script that included going to school followed by university so that one could obtain an "office job" (white-collar job). For my participants "office job" was a stand-in for work that was secure and not menial; it is the type of work undertaken by educated and professional women, rather than the uneducated women who might be engaged in manual labor or who set up their own petty business enterprises. To be educated meant that one worked in an office. Such work was 
also legitimized by the broader community for single women; once married, however, girls whose husbands could provide often did not work in offices either. By avoiding work after marriage, women could also signal their social-class standing. Most of my participants, however, could not afford such luxury. They knew that regardless of their marital status, they would need to work in order to make ends meet. Sania (age twenty-one) explained that "education is for a job." She was adamant that it was important for girls to get an education so that they could support their families financially. Hence, education was seen as proper consumption for low-income girls-it was a commodity that they consumed today in order to reap its rewards in the future. Any deviation from this pathway-such as completion of only ten grades of schooling, opting for vocational or technical training, taking time off to care for family members, or taking a couple of years off to memorize the Quran ${ }^{46}$ - was a source of anxiety because it would inevitably decrease the chances of obtaining a white-collar job. Sabiha (age sixteen) explained: "no degree, no job, no identity."

This perspective of education has created an atmosphere where acquisition of credentials is emphasized over education's potential for effecting social justice or democratic change. My participants, for instance, pointed to the increasing "credentialization of education" (Anita, age twenty-one), which produced a "businesslike movement of life" (Nadia). Anita complained that "education has become a business. One now needs a master's or even a Ph.D. to get a decent job. We are unable to pursue our interests because it is difficult to convince ourselves and others to pursue disciplines that cannot be converted into money quickly."

Similarly, Ram Chand (a parent) noted that children see education as a pathway to aasaish (luxury) and have a "utilitarian and egocentric view of education," which is often "self-serving and oriented toward materialism and consumption." $\mathrm{He}$ further observed that with the transformation of schooling into a commodity, students are read as consumers and school-student or teacher-student relationships are viewed as transactions. He went on to describe these trends succinctly:

These days education has become commercialized and students are clients. It is as if schools provide customer care. Schools now see children as customers, versus the caring role that a parental figure might have. Commercialization also means that schools need profits, so they give what the child wants. In the current market-driven, degreeoriented environment, students want high percentages [in public examinations] in order to get into highly sought-after professions, and schools try to provide that.

Likewise, Yasmeen, a parent and an assistant professor at a local college bemoaned, "education these days is a machine for earning money."

What Ram Chand, Yasmeen, Anita, and Nadia are pointing out is the neoliberalization of everyday life and education. The dominance of economic rationality has reduced all aspects of schooling to economic calculations. Paul Bylsma, an American scholar who has examined the evolution of the American 
higher-education system, observes that today, "the transactional nature of investing resources toward a diploma is emphasized over the transformational nature of learning toward the end of democratic deliberation and a community-based vision of flourishing and social prosperity.... The telos ... of higher education is in danger of being reduced to producing quantifiably successful graduates seeking to flourish in shallow and material terms." ${ }^{47}$ Bylsma goes on to observe that the model citizen of today is imagined as someone who has the "ability to choose between universally sufficient and available options" and "will make the most rational and responsible decision for their own welfare. . . . The model citizen in the neoliberal state is active, entrepreneurial, rational, responsible, ultimately affluent, and thus morally superior." ${ }^{48}$ This is exactly the sentiment that sixteen-year-old Sabiha expressed: "even if you are a bad human being you are everything if have a degree and high paying job." Consuming education to obtain a degree and to transform one's self into a productive worker, thus, appeared as the dominant rationale for pursuing schooling. It was not only a practice that was required of my participants due to their social class positioning, but also a pathway that was marked as the most logical and commonsensical for all youth.

My participants, however, noted that girls from upper-class backgrounds did not consume schooling in the same way. For them education conferred a form of respectability that opened doors to better marriage prospects. As Nabila noted, "Some girls believe in inserting 'Engineer' or 'Doctor' before their names so they can get good marriage proposals." Sanum (age twenty-one) also explained that "given the attention to education these days everyone wants an educated wife; the more educated you are, the better your marriage prospects." Since being a doctor was considered a high achievement for girls in this community, I noticed that several girls in my focus groups as well as beyond were pursuing the field of medicine. Their purpose for doing so, however, was not necessarily appreciated by Nabila and Sanum. Sanum, who was from a low-income family, for instance, had been struggling to complete her M.B.B.S. (medical degree) and anxiously wanted to start working. She complained: "many [girls] will just do M.B.B.S. and not do house jobs (residencies)." This, to her, appeared as an improper consumption of education because it limited the opportunities for those girls who genuinely needed to pursue the degree to obtain a means of earning a living. This critique, however, does not mean that girls from low-income backgrounds do not see education as a pathway toward marriageability. Indeed, Sanum noted: "Education is a requirement for a better life partner." She defined a successful girl as "one who gets a good life partner, has the ability to earn a living, and knows how to run her household." For girls from low-income backgrounds, this equates to what Saadia (age sixteen) termed as the "triple shift"—“women have triple shift—ghar [home], bachay [children], job."

In contrast, Maria (age fifteen), a girl from a relatively well-to-do middle-class background, did not see herself as being the primary wage earner in the future. 
She wanted to have the proper qualifications to earn, "if needed." More significant than waged work for Maria was the ability that education would bestow on her to manage her household effectively and educate her (female) children in an increasingly competitive environment: "Women are the primary caregivers. Boys can learn from outside but girls learn at home. Boys' nourishment can happen from outside." The trend of upper- and middle-class girls' pursuit of education for reasons other than joining the formal labor force has also been found in other settings in South Asia and the Middle East. For instance, while Jordan boasts high enrollment rates for both primary and secondary schooling, this has not been accompanied by lower birth rates and higher female workforce participation as typically envisioned by the development narrative. Fida Adely, in her ethnographic study of girls' educational experiences in Jordon, finds that highly educated middle-class women choose to stay at home. ${ }^{49}$ The World Bank has termed this as a "gender paradox." However, Adely argues that these trends become intelligible when we take into account norms around marriageability, class, and respectability. Girls indeed value education, but for different reasons and toward different ends. Adely concludes that "the logic of the World Bank can be turned on its head ... as people have appropriated the imperative of education for their own status concerns and needs, a reminder of the limits of the power of global development institutions." ${ }_{50}$

Likewise, Willy Oppenheim in his study in an agrarian village in Punjab, Pakistan, also found that parents valued education not only for the potential for girls to be able to secure jobs but also due to education's enabling girls to "make a house very well" and train children, as they are "responsible for many generations." ${ }^{11}$ Oppenheim thus argues that the "social value of schooling can shift and diverge within a given community." ${ }^{2}$ My participant, Maria, like Adely's middleclass participants, is neither the kind of subject envisioned by transnational girls' education discourse, nor the "consumer-worker" desired by the nation. Although she conforms to the neoliberal principles of self-interest and is driven by economic logics, these same principles lead her to consume education differently. She seeks to become a better mother and prepare her children for a competitive world. These practices also help her to signal her social class, as only upper-class women can afford to become full-time mothers. She lacks the desire and the financial drive to enter the labor force that both the neoliberal and national projects deem imperative.

These differences in how education is consumed are reminiscent of the purpose of education for ashraf girls, articulated at the turn of the twentieth century. Indeed, whereas Sharifun was urged by Muhammadi Begum to obtain an education so that she could engage in waged work available to struggling families, well-to-do girls were to acquire an education to manage their households and train their children. My focus-group participants engaged in a similar reasoning to some extent. Much like the ashraf women of the turn of the twentieth century, Maria consumed education to improve her domestic-management skills and secure good marriage prospects. Girls from low-middle-income backgrounds (the majority of my 
participants), however, saw schooling primarily as a pathway to waged work. What is different in the present moment, however, is the greater public discourse around the necessity for women to enter the workforce. Whereas, at the turn of the twentieth century, women avoided working for money until pressed to do so, in our own time it seemed an inevitable reality for most of my participants. The fact that they would need to work to make ends meet was not an idea that they had to be socialized into. They already believed that it was their personal responsibility to improve their lives without relying on the state.

This is perhaps also one of the reasons that not many of my participants connected education to citizenship; while education was seen as a practice that would enhance the self, it appeared to contribute nothing toward enhancing the development of the nation. This is a stark contrast to earlier discourses, whereby education was expected to transform young people into ideal Pakistani citizens. Recall Asaf Hussain's interviewees from chapter 3, who consistently drew connections between education and contribution to the new nation of Pakistan. I suspect that since the Pakistani state has been failing to provide basic services to its citizens, my participants have disciplined themselves into citizen-workers who are expected to strive to improve their own lot without guarantees from the state. Girls like Nadia then see their inability to secure a job as their personal failing.

So, there are different but overlapping patterns of how schooling is consumed. In my case study, for upper-middle-class girls, schooling provided potential rewards in the form of marriage proposals as well as the "option" of entering the formal workforce if needed. For low-income participants, while schooling had similar social meanings, it was first and foremost a means to access future waged work, although they experienced intense scrutiny and precarity in the process. It is this latter group that put forth a critique of schooling for failing to deliver on its promise of prosperity and erasing particular identitarian knowledges.

\section{CONTESTING SCHOOL KNOWLEDGES}

School knowledge can be theorized as all aspects that students learn in school whether intentional or unintentional. These knowledges provide a glimpse into the kinds of discursive possibilities that are available for students to (re)make themselves. I present two critiques of school knowledges that emerged during the focus groups. In this section, I discuss how participants critiqued the exclusion of skillsbased training from official school curricula, which limited their possibilities for becoming economically independent; and in the next section, I explain how they noted that in privileging particular moral regimes, schools erased knowledges about religious minorities - in their case, Shia Muslims. This evidence should be read in light of how schooling has evolved in postindependence Pakistan (and also India). Krishna Kumar argues that one of the key consequences of colonial education policies has been the disconnect between school knowledges and everyday 
knowledge. ${ }^{53}$ And, in the context of Pakistan, we might consider teachings of Islam to be a part of the latter.

While participants saw schooling as a pathway to white-collar jobs, they also recognized that "there were no guarantees" (Fazila, age seventeen). Fazila added, "After all, how many doctors and engineers does a nation need? Who will do the rest of the work?" Likewise, Sanum questioned: "If people do not choose those [blue-collar jobs] then the nation loses. Who will fulfill the small roles?" It was clear that my participants understood the classed nature of "office jobs." Such jobs often went to those who had the requisite cultural and social capital. This led us into conversations around the devaluation of hunar (skills) in society and the decline of apprenticeship systems due to the privileging of particular knowledges in formal schooling. For example, participants noted that vocational or crafts-based education was looked down upon and available only in nonmainstream educative spaces such as technical boards or informal apprenticeship arrangements. These spaces of learning and forms of knowledges were assumed to be reserved for unparh loag (the uneducated people). As Gulnaz (age thirteen) elaborated, "we live in a twotracked society-those who have 'education' and those who have hunar; the latter are often deemed to be unparh [uneducated]."

At the same time, many participants recognized that having a hunar-especially one that could be monetized-is useful in today's context where schooling is failing to deliver on its promise of jobs that provide financial security. They identified tailoring, fashion designing, beautician, mobile technology repair, electronics repair, computer hardware maintenance, and plumbing as some economic domains where jobs were plentiful but from which "educated" people stayed away. Participants explained that learning such skills is considered "low status" because "education" entails progressing through the chain of school, college, and university, and ending with an "office job." They cited the example of many people whom they knew personally who worked as tailors, blacksmiths, and plumbers and made a better income than many "educated" people with master's degrees. ${ }^{54}$ Laila (mathematics and science teacher), for instance, gave specific examples of many children she knew at her brother's apprenticeship arrangement who were brighter than her own students in school. Asma (mathematics teacher) also provided similar examples. Both of these teachers taught in schools that catered to children from low-income families, and argued that while official school knowledges were deemed more worthy of study, hunar would in fact be more useful for their students and prevent economic hardship.

The participants' concerns around unemployment seem to stem from their personal experience of "educated" family members being unable to secure adequate employment, as I have noted in my previous work with this community.55 This rings especially true in the case of women in Pakistan. According to data available in 2014-15, unemployment rates for women in urban areas is nearly 20 percent, with female labor force participation only around 10 percent. ${ }^{56}$ With over 18 
percent of the urban population below the poverty line, ${ }^{57}$ and nearly 39 percent estimated to be vulnerable to poverty, ${ }^{58}$ a low labor-force participation likely indicates that most women are stuck working in the informal sector. In fact, many women in the community where I conducted the study made an income by running home-based beauty parlors, boutiques, and producing handicrafts (such as rallis, quilts). Such home-based, contingent work often does not provide the labor protections of full-time work, as Anita Weiss's work with women in home-based cottage industries in the Walled City of Lahore during the late 1980 os illustrates. ${ }^{59}$ These women had to often rely on middle-men for raw materials and for bringing products to the market, which decreased their ability to negotiate better rates for their work. Even in the 1980s, however, Weiss noted the significant lack of technical schools for girls where they could learn industry-related skills. ${ }^{60}$

When all else fails, girls from low-income backgrounds often end up in factories. Although only a very small percentage of girls whom I interviewed would fall in this category, manual labor in factories was not outside the scope of their imaginations, since many knew others who indeed worked in a nearby factory. While factory jobs are valorized by girls' education advocates like Nicholas Kristof, who in his New York Times article "Two Cheers for Sweatshops," ${ }^{61}$ praises factory jobs as a pathway to address poverty, factories in Pakistan are notorious for exploiting workers. This was clearly visible in the May 2017 protests of the apparel brand Khaadi in Pakistan. Khaadi's employees have detailed their mistreatment-from long working days and low wages to lack of job security and resistance to unionization. Their cries are met by a government that has been unwilling to enforce labor laws. With the global focus on women's participation in the labor force, it would seem logical that state and nonstate actors would seek to improve the status of women working in the formal economy through higher wages, better living conditions, opportunities to enhance skills, and provision of insurance. However, that has not been the case in Pakistan. Implementing labor protections is not in the interest of global capital and the neoliberal state. Nike, the global leader of Girl Effect, for instance, closed its factories in South Korea when women started organizing for better wages. ${ }^{62}$

My participants' desire for hunar can be read, then, as an effort to devise ways to access income security in an environment where schooling is not fulfilling its promise of economic independence. In fact, a 2014 "World of Work" report by the International Labour Organization argued that it is the quality of work, and not work in itself, that can alleviate poverty. The report noted that half of the workers in developing countries are twice as likely to be trapped in a "vicious circle of lowproductivity employment, poor remuneration and limited ability to invest in their families' health and education, which in turn reduces the likelihood that current and subsequent generations will be able to move up the productivity and income ladders." ${ }_{33}$ When properly supported, women can even thrive in male-dominated professions that require specialized skills. Consider the Aga Khan Cultural 
Services' Women Social Enterprise (recently renamed CIQAM) project, in the village of Altit in Hunza. The project trains poor and marginalized women in professions dominated by men, such as carpentry, furniture making, and woodworking. Entrance in these male-dominated professions translates into better incomes for these women than would otherwise be possible in feminized professions of handicrafts or through factory work. Projects like these, however, are rare and require not only initial capital but extensive work in the community to create an authorizing environment for women to work. Such projects call for development interventions and vocational training that are long-term and participatory. They also call into question the types of knowledges and skills centered in formal schooling, pointing toward a broadening of the definition of what it means to be educated.

My participants' calls for learning concrete skills were hence aimed at securing alternate ways for survival and decreasing their dependence on men. Instead of opting out of schooling, they called for modifying it in ways that they thought would fulfill their needs and give them viable life-scripts. These insights show that girls in Pakistan actively engage with school knowledges and understand the ways in which partaking in particular learning opportunities can increase or decrease their chances of a "good life."

\section{RELIGION, IDENTITY, AND MORAL INSTRUCTION}

Moral instruction of young people remains a crucial objective of schools. That is precisely why in both chapters 2 and 3 we observed extensive debate about English language/literature, dress codes, and the teaching of Christianity in schools. These debates have continued to the present, but with a sectarian tinge. The state of Pakistan has drawn on the institution of schooling to produce proper "Muslims" and "Pakistanis." It has sought to do this by introducing elements of Muslim morality in schools through courses such as Islamyat and Pakistan Studies, appointments of public school teachers, and dress codes. Indeed, the National Education Policy published in 2009 recognizes the "importance of Islamic values" and emphasizes the "need for developing Pakistani children as proud Pakistani citizens having strong faith in religion and religious teachings as well as the cultural values and traditions of the Pakistani society." ${ }^{4}$

Girls' dress codes continue to be a site of tension in these debates. In October 2017, for instance, a public university, the International Islamic University of Islamabad, issued a circular warning that women not conforming to its dress code will be punished. The dress code was defined as: "Shalwar Qameez with at least knee-length shirt, dress should not be see-through, deep necks strictly prohibited, sleeveless shirts are not allowed, trousers are allowed only with long shirts, skinny jeans, tights and capris are not allowed, dupatta or scarf is compulsory with all dresses, make-up and heavy jewellery [sic] are not allowed, and high heels are also not allowed." ${ }^{5}$ Even at private educational institutions girls are disciplined around 
what they can and cannot wear. Earlier in October 2017, a female faculty member at the Institute of Business Management (IoBM) in Karachi was reprimanded by a security guard over what she was wearing. The faculty member's Facebook post about this incident went viral. It noted: “Today, I was rudely stopped at the [IoBM] gate by a weird man who said he was the security head, and told that I wasn't 'following the dress code'. . . . Ladies, please help me understand, how I am a security threat?" 66 The post included a photo of this faculty member wearing a white shirt and a long scarf over pants.

Anxiety over women's dress is just one example of how the state as well as other societal institutions and individuals advance their particularized assumptions about public piety and morality. These contestations often spill over into the realm of curriculum as well, as I will describe later. Significantly, these debates now take on an explicit sectarian tinge. Since state-sponsored interpretation of Islam in Pakistan has been Sunni, it marginalizes minority interpretations of the faith. The community where I worked has faced persecution and threats of excommunication in the past. It has, therefore, developed a strong sense of identity as a minority, and engages in boundary-making practices, such as living in gated neighborhoods and establishing strong social-welfare institutions to meet the needs of its members. Furthermore, it has developed evening religious education services, where young members of the community learn about their interpretation of Islam. At the Religious Education Center, classes are held every weekday evening for an hour, on topics such as Shia theology, Muslim history, and prayers.

While I was conducting focus groups, one of the key anxieties that emerged was around the religious formation of girls and the religious identity of the community. Some female participants complained about the lack of time, and consequently interest, to attend REC classes. Sidra (age sixteen) observed that, "we prioritize rational knowledges of school and think religious teachings of REC teachers are stagnant." Similarly, Nadia commented that in the contemporary environment, where money reigns supreme, REC is devalued because attendance is free: "I have a nonserious attitude toward REC. We have no time. We pay for secular education and don't pay for REC." I, therefore, decided to include additional focus groups with REC teachers to explore this theme further. In this section, I provide a glimpse into my conversations with the teachers around the need for religious knowledges (read: Shia theology and moral instruction). Teachers' narratives become intelligible when we situate them within the national project of producing "Muslim" (read: Sunni) subjects through schooling.

REC teachers explained that "mazhab [religion] is an integral part [of life] and it is important for young people to follow religion” (Naureen, REC teacher). For them knowledge of religion was essential for producing an ethical subject. They were, therefore, concerned about the lack of attendance at RECs. They worried that schools did not expose students to the kind of behaviors, knowledges, and sensibilities that their interpretation of Islam espoused. They also believed that 
religious education was crucial for students to be able to articulate their identity in a hostile environment. This was an implicit reference to Sunni domination in Pakistan. Rashida, a veteran teacher of eighteen years, bemoaned that students and parents alike ignored religious knowledge acquisition due to the "overwhelming pressures of secular schools." Since students spent the majority of their time in schools, at tuitions, or doing homework, they had little time left for REC classes. The teachers believed that this was a problem given that community members are often asked to explain their interpretation of Islam. Rashida observed that, "there is much misconception in the population about us [Shia Muslims], and children need the REC for resolution." Rashida's narrative suggests that she was anxious about her minority interpretation of Islam being made invisible in and through school knowledges, and feared erasure of her community's identity.

Significantly, in the context of Pakistan, where the national identity is intricately linked to Islam, being the "wrong" kind of Muslim can bring out the wrath of the populace as well as the state. The persecution and discrimination of members of the Ahmadiyya community in Pakistan is a case in point. Members of this community were first persecuted in 1953 during the Lahore riots (led by Islamist parties, including Jamaat-e-Islami), ${ }^{67}$ followed by another massive persecution effort launched by Islamist parties in 1974, which led to the government of Pakistan passing a constitutional amendment declaring members of the community as kafirs (unbelievers). In 1984, another amendment was made which restricted the community from calling itself "Muslim." On May 28, 2010, approximately ninety members of the Ahmadiyya community were killed during attacks on two mosques; and, as I write this chapter in October 2017, three members have been sentenced to death on blasphemy charges. This time the flames of violence have been stoked by the son-in-law of the former Pakistani prime minister Nawaz Sharif, perhaps in a bid to distract attention from an ongoing investigation into the family's corruption. In the context of these examples, and everyday sectarian violence against Shia groups as well, the community where I conducted research has remained very cautious. Members realized that schools played a critical role in erasing their subject positions, and hence emphasized that children of the community participate in the REC.

Their fears around erasure are not unique. Consider the controversies in relation to textbooks which shed light on the political stakes of school curricula. Textbooks in Pakistan are prepared under the guidance of and approved by the Central/National Curriculum Wing of the Ministry of Education. They are published, distributed, and marketed by the four Provincial Textbook Boards in their respective jurisdictions. In 2014, the political party Jamaat-e-Islami in the KhyberPakhtunkhwa province demanded that chapters on Muslim personalities that had been removed by the previous provincial government in 2006 be reinstated, and that "all secular, un-Islamic chapters be removed."' ${ }^{8}$ It asked for the addition of eighteen Quranic verses to the ninth-grade chemistry book and for replacing "Good morning" with "Assalam-o-alaikum" in first-grade textbooks. ${ }^{69}$ Their request also 
included the removal of what they deemed to be inappropriate images, specifically pictures of schoolgirls with their heads uncovered. The Tehrik-e-Insaaf (political party)-led government acquiesced to their demands. This was criticized by others as giving in to extremist interpretations of Islam. Between 2000 and 2005, the northern areas of Pakistan had been engulfed in another textbook-related controversy when the state introduced new, overtly Sunni textbooks. The local Shia population agitated for a more balanced curriculum. The events culminated in violent confrontations during 2004-5. These controversies show how contestation over school knowledges is also a contestation over identity and belonging. As anthropologist Nosheen Ali, writing about this incident, notes:

The right to have representation of Shia identity in school textbooks was seen by Shia protestors ... as a mode for securing recognition and cultural reproduction.... Through the idiom of religion, the Shia subjects of the Northern Areas were also articulating a political demand for legitimate, substantive inclusion in a polity that has historically denied them even the most basic citizenship rights.... Hence, asserting religious difference and getting it politically recognized in official arenas such as education becomes a potential, and perhaps the only viable way to achieve similarity and equal treatment as citizens of the Islamic Republic of Pakistan. ${ }^{70}$

It is against this background that I interpret Rashida's comments about misconceptions about her community and the desire that young women and men engage with religious knowledges. She saw schools as potentially erasing already precarious knowledges about minority communities in Pakistan. These fears also compelled other teachers to advocate for greater space for Shia religious knowledges. As Hina (REC teacher) said, "we should maintain balance between din [spiritual] and duniya [material]; secular education only focuses on duniya." However, teachers did not seek to replace "secular" schools with RECs. Instead, for them the REC provided an additional space for learning. Unlike the mainstream madrasas in Pakistan, which are often compelled by the state to define their "usefulness," and have become a site of constant intervention and reform, RECs are not viewed as threats because they do not seek to substitute for public schooling.

At this point it is also crucial to note the slippage between religious/Shia knowledges and moral instruction that often happened during focus-group conversations. Teachers emphasized that "religious knowledge" (dini ilm) was important in order to engender a distinctly Shia identity, and believed that such an identity would shape the public and private conduct of young people in different ways when compared to school knowledges. For example, our conversations about REC often veered toward the increasing pressures of social media, the incitement to display intimate details about one's life for public consumption, the collapse of the joint family system, and the increasing isolation of young men. All of these were areas that the teachers believed could be addressed through proper moral instruction, a task that secular schools were not adept at. Teachers also noted that parents, 
too, were ill-equipped to address such issues, since they were often engrossed in their own difficult lives, just barely surviving. So, they considered the RECs and their own profession of pastoral care/teaching as ideally placed to address the needs of young men and women.

\section{BECOMING EDUCATED GIRLS}

The transnational discourse on girls' education positions girls in the global South as being on the precipice of failure if not saved by education. Education is expected to help delay marriage and childbearing, prepare girls to enter the workforce, and so propel them onto paths of success and prosperity. This system of reasoning articulates girls as agents who can take personal responsibility for their development, secure rights, and gain economic empowerment; and schooling appears as the primary social project that can unfold this progress and emancipation. However, when we actually consider the realities of girls (as glimpsed in the narratives of the participants), we see that schooling is at times experienced in problematic ways. Social class often mediates experiences of schooling. The calls for self-making embedded in the current articulation of girls' education produce different possibilities and limitations for girls, especially those from disadvantaged backgrounds. Since my focus-group participants belonged to socioeconomic classes that had just begun to access the privileges of the middle class, they found themselves simultaneously enticed by the promises of upward mobility that neoliberal visions of schooling offered and constrained by the absence of the economic and social scaffolding necessary for girls to emerge successfully out of schools. Nadia's case demonstrates this aptly-she identified the deep economic and social investment required by her family to ensure access to good schooling and how these sacrifices produced additional precarities for her. Likewise, girls from lowmiddle-class backgrounds often called for a rethinking of school knowledges, so that they could eventually become economically independent. We also saw how schooling appeared to be problematic for religious minorities, as they grappled with the implications of moral instruction in schools dominated by Sunni ideologies. Since schools are seen as being ill-equipped to provide moral instruction, nonformal educative spaces (such as the RECs and the home, as the next chapter will show) have emerged as the ideal sites for engendering an ethical subjectivity. This move recenters the patriarchal family as well as religious leaders, assigning them the authority to regulate youth.

The case study centered in this chapter reveals how concerns around respectability, religious formation, and orientation to waged work continue to inform conceptualizations of ideal girlhood. The specificities of social class and religious orientation in particular signal that it is impossible to imagine homogenized girlsubjects. Furthermore, the evidence in this chapter, as well as the progress made 
in Pakistan to close the gender gap in education, suggests that at least in the urban areas, education for girls is viewed as an important endeavor. While parents engage in different evaluations around what type and how much education to give to girls, and girls consume schooling for different purposes, there is plenty of evidence to suggest that their education is not taboo. According to a 2009 Pew survey, 87 percent of Pakistanis believe that education is equally important for boys and girls. ${ }^{71}$

This background helps us make sense of the backlash against Malala in Pakistan. The backlash, I argue, has less to do with Pakistanis' discomfort with girls' education and more to do with what Malala represents in relation to Pakistan and Muslims. Given Malala's prominent stature these days, and the unfortunate abundance of Pakistan "experts" or prowomen journalists-such as Nicholas Kristof-who draw on Malala to articulate reductive ideas about Pakistan, before closing the chapter I will briefly analyze Malala's uptake in the discursive regime of girls' education.

\section{Returning to Malala}

Malala, the idea, tells a particular story about Islam and the people of Pakistan. She is represented as the girl who defied the cultural logics operative in Pakistan, and who now embodies a transnational, secular modernity exemplified by her emphasis on the autonomous self, enactment of choice, advocacy for freedom, and arguments for gender equality. ${ }^{72}$ Instead of being a symbol of the courage of Muslims and Pakistanis to stand up against local forms of violence, Malala is shown to be an exception. Through extensive media coverage and uptake of her image by international organizations, she is individualized in her courage and successful performance of empowerment. She is presented as succeeding against all odds, as a heroine or, as Chelsea Clinton in Time magazine calls her, the "champion for girls everywhere." ${ }^{73}$ She is made into an exception by practices such as celebrating "Malala Day," receiving the Nobel Peace Prize, and book deals. Even the title of her book, I Am Malala: The Girl Who Stood Up for Education and Was Shot by the Taliban, centers on her person, emphasizing her uniqueness.

To create Malala as an exception entails individualizing and abstracting her from the local environment and cultures, and connecting her positive attributes to another source, such as her formal education, desire for success, and ambition. Her courage, then, is not read as grounded in Pashtun cultural practices that valorize social justice. Instead, she is positioned as a singular force against local customs and cultural elements. Malala's transnational uptake, then, sustains assumptions that transform all Pakistani, Muslim men into terrorists, and all Muslim women into victims or potential victims. Malala is distanced from other Muslim girls. She is made to simultaneously stand in for, represent, and symbolize the oppressed Muslim girls, and positioned as the empowered girl who is not one of them. The idea of Malala denies other Muslim girls similar forms of empowered 
subjectivities. It sustains the façade of Islam as an oppressive religion, positioning interventions-such as universal education of girls, empowerment projects, or even drone attacks-as necessary or even ethically imperative.

However, reading I Am Malala against the grain highlights Malala's radical specificity as a Muslim and as a Pakistani. ${ }^{74}$ In this book, we come face to face with vibrant cultures and societies, an abundance of strong-willed women, and kind, thoughtful men. The text reveals aspects of the Pushtun culture and its people: we learn about their hospitality, ${ }^{75}$ their oral traditions of poetry, ${ }^{76}$ their love for knowledge, ${ }^{77}$ the imperatives for kindness, ${ }^{78}$ and the beauty and precarity of mountain societies. ${ }^{79}$ There are incidences when the religion of Islam emerges as a source of generosity and peace. For instance, the only charities that stayed behind to help local people after the earthquake in 2005 were local Muslim charities. ${ }^{80}$

In I Am Malala, we encounter women who shatter the trope of the victimized Muslim woman awaiting a savior. From Malala's namesake, the Malalai of Maiwand, who fought the British, ${ }^{8_{1}}$ and her great-grandmother, who "walked forty miles alone over mountains" in order to appeal for the release of her son, ${ }^{82}$ to the women of Spal Bandi "who had great freedom and were not hidden away, ${ }^{13}$ we find evidence of women's tenacity within socioeconomic and political constraints. These glimpses into the lives of Muslim women add complexity to, and work against, the narrative that reduces freedom to "resistance" against local practices. It would be simplistic to read these actions axiomatically as moments of women's empowerment and agency; however, they do signal the possibility of differently constituted lives where empowerment and agency may or may not look the same as that proposed by western liberal feminists. Here, women seem to be working to establish their rights within local frameworks, and against domestic and global patriarchies.

We also come across a wide range of kind, thoughtful, and intelligent Muslim men who work for the betterment of their communities, including contesting the advances of the local Taliban-inspired militants. Figures such as Malala's father, Ziauddin Yousafzai (an activist); Jehan Yousafzai (Zaiuddin's cousin, who brought a gift upon Malala’s birth); ${ }^{84}$ Uncle Dada (a conscientious teacher), ${ }^{85}$ Nasir Pacha (a stranger who helped Ziauddin complete his college education); ${ }^{86}$ Akbar Khan (Ziauddin's mentor); ${ }^{87}$ Usman Bhai Jan (the beloved school-bus driver); ${ }^{88}$ and Dr. Javid (the Pakistani-British doctor who arranged Malala's hospitalization in the United Kingdom), ${ }^{89}$ all strike at the heart of the ahistoricized and decontextualized figure of the violent, brown, Muslim man. The key Taliban characters in the book, Fazlullah, Sufi Mohammad, and the mufti who tried to close Ziauddin's school, are viewed as anomalies, and their actions are contested by local men and women alike. Indeed, the challenge to Fazlullah comes from within the community-the Pushtuns called their assembly of elders to oppose him, ${ }^{\circ \circ}$ and those who viewed him favorably earlier retracted their support when his initiatives did not align with their sensibilities. ${ }^{91}$ Challenges to Fazlullah's militancy were also featured 
prominently in the local media. ${ }^{92}$ I Am Malala is, then, a radically specific story, one which gets erased as all the specificity is removed in western media discourses and Malala is transformed into a caricatured, first-oppressed, now-empowered girl.

The contestation around Malala in Pakistan, thus, represents the struggle for the meaning of Pakistan and Muslim; it is less about girls' education or any protest against the education of girls. It also signifies a struggle against certain meanings imposed or implied by volunteers, donors, and aid agencies of the global North. Evidence in this chapter clearly shows a remarkable desire for education in Pakistan. That education remains a classed enterprise and does not afford possibilities for all is a key issue at stake. This issue, however, is sidelined in aid and development discourses. Rather, what is highlighted is a false assumption around Pakistanis' and Muslims' animosity toward education, and Malala's image is often taken up in the service of that ideological project. 